Triwara Buddhi Satyarini, Sutrisno,

Diah Rina Kamardiani

123Program Studi A gribisnis Fakultas

Pertanian

Universitas M uhammadiyah Yogyakarta

Jalan Brawijaya Tamantirto, Kasihan,

Bantul, Daerah Ismiewa Yogyakarta 55183

Email: sutrisno_agrifp@umy.ac.id

\section{Festival Kuliner Wedang Ereng- Ereng Dalam Rangka Mendukung Desa Wisata Seloharjo}

Wedang Ereng-Ereng C ulinary Festival To Support Tourism Village 0 f Seloharjo

https:/ / doi.org/ 10.18196/ bdr.7156

\begin{abstract}
Wedang Ereng-ereng Culinary Festival activity is held in order to support the mandate of Seloharjo village as a tourism village. Based on three natural potentials, namely Goa J epang, Tuk Surocolo, and Goa Sunan Mas, Wedang Ereng-ereng is expected to become a typical culinary attraction. This festival is intended as an internal and external promotion effort as well as to make Wedang Ereng-ereng as the tourism icon of Seloharjo. The festival activity is carried out in four stages, namely: preparation, socialization, festival implementation, and follow-up plans. The community is involved in all stages as the main actors of Seloharjo tourism development. This festival has succeeded in making people aware of the potential and opportunities of Wedang Ereng-ereng as a source of community income.

Keywords: wedang ereng-ereng, culinary, tourism village
\end{abstract}

\title{
PENDAHULUAN
}

D esa Seloharjo telah mendapatkan mandat sebagai D esa W isata \& Budaya dari D inas Pariwisata Kabupaten Bantul sejak tahun 2014. Mandat ini diberikan berdasarkan beberapa potensi baik potensi alam maupun potensi sosial budaya yang lain. Beberapa potensi alam yang layak dikembangkan menjadi tujuan wisata di D esa Seloharjo meliputi Goa Jepang, mata air Tuk Surocolo, dan G oa Sunan Mas.

G oa Jepang berada di puncak M erangi, D esa Seloharjo, dengan 19 goa peninggalan masa pendudukan Jepang. G oa Jepang menjadi objek wisata peninggalan sejarah. Dari atas Puncak M erangi wisatawan dapat menyaksikan panorama laut selatan dan bentangan kawasan Pantai Parangtritis hingga Pantai D epok serta muara Sungai O pak. Tuk Surocolo terletak di perbatasan D usun N greco dan Poyahan, Seloharjo. Terdapat 2 sumber mata air di Tuk Surocolo yang dikenal dengan Sendang Putri dan Sendang Kakung. D i masingmasing sendang, terdapat sebuah arca yang diperkirakan berusia sama dengan candi 
Borobudur. Di area Tuk Surocolo terdapat Goa Sunan M as yang diyakini dibuat pada masa Kerajaan Mataram Islam oleh RM Sutikno yang berjuluk Sunan Mas yang merupakan keturunan Amangkurat II.

Tiga situs sejarah tersebut yang mendorong Pemda Bantul melalui Dinas Pariwisata agar segera mewujudkan D esa Seloharjo menjadi D esa W isata. Saat ini tempat-tempat tersebut sudah mulai ramai dikunjungi wisatawan karena informasi dari mulut ke mulut dan efek komunikasi media sosial. Pertimban gan lain adalah perlunya upaya perlindungan situs-situs sejarah yang dapat memperkaya khasanah budaya masyarakat dan bangsa Indonesia.

Beberapa upaya nyata telah dilakukan oleh pemerintah baik Pemkab Bantul maupun Pemprov DIY untuk mendukung wisata di Seloharjo. U paya tersebut antara lain bantuan pengembangan fisik untuk penataan situs, pembangunan sarana pen dopo kesenian, toilet dan mushola, serta pembanguan jalan. Perencanaan lain demi terwujudnya desa wisata ini, akan ada bantuan penerangan jalan dan studi kelayakan untuk memanfaatkan sungai opak sebagai objek wisata air.

Pada sisi lain, pemerintah telah berkali-kali menyelenggarakan semacam festival dan kirab budaya untuk melihat dan mengidentifikasi potensi kesenian dan budaya yang tumbuh dan berkembang di Seloharjo. Pemerintah juga telah resmi membentuk Kelompok Sadar W isata (Pokdarwis) terutama di D usun N greco dan Poyahan, dua dusun yang sangat dekat dengan obyek wisata yang akan dikembangkan.

Beberapa faktor pendukung D esa Seloharjo menjadi D esa W isata dan Budaya serta memiliki prospek cerah di masa depan yakni :

1. Letak geografis $D$ esa Seloharjo yang sangat strategis karena dilalui oleh Jalur W isata dari Jogja menuju objek wisata pantai yaitu Parangtritis, Parangkusumo dan Depok. Jika melalui jalur jalan Imogiri, maka D esa Seloharjo dilalui persis (langsung) artinya wisatawan yang menuju Parangtritis dan sekitarnya akan melewati langsung Desa Seloharjo. Jika melewati jalur Jogja Jalan Parangtritis, maka hanya butuh berbelok sekitar 1 km dari jalan Parangtritis, sudah sampai sampai lokasi W isata D esa Seloharjo.

2. W isata D esa Seloharjo diyakini akan menjadi sajian utama maupun pelengkap wisata Pantai Parangtritis, Parangkusumo, maupun D epok dan sekitarnya. H al ini dikarenakan objek yang ditawarkan unik dan jarak tempuh hanya berkisar 2 - $5 \mathrm{~km}$ saja dari wisata pantai yang telah ada sebelumnya.

3. W isata pemandangan (view) di sekitar Goa Jepang atau Puncak M eranggi memiliki daya tarik tersendiri yang sampai saat ini terus ramai dikunjungi orangakibat promosi 
person-by person dan efek media sosial

4. Telah dilakukan survei kesiapan masyarakat tentang pengembangan D esa W isata Seloharjo oleh Tim KKN Tematik U MY, terutama di 3 dusun penyangga yaitu N greco, Poyahan, dan Jelapan, bahwa sebagian besar (> 90 \%) masyarakat setuju apabila Seloharjo akan dikembangkan menjadi Desa Wisata dan $>80 \%$ warga siap berpartisipasi terutama berpartisipasi dalam kegiatan yang dikembangkan dalam desa wisata

5. Telah dilakukan diskusi dengan Perangkat Desa / Dusun serta Pokdarwis, bahwa masyarakat harusberpartisi pasi dalam menyongsong perintisan D esa Seloharjo menjadi desa wisata dan budaya. Peran aktif tersebut mulai dari penguatan kelembagaan masyarakat pengelola D esa W isata, aktif dalam pengelolaan sajian desa wisata maupun mempersiapkan daya dukung yang kondusif bagi pengembangan desa wisata

Selain permasalahan penataan kawasan, permasalahan lain yang dihadapi desa wisata Seloharjo adalah belum adanya kuliner khas yang menjadi daya tarik. Kedatangan wisatawan di area Puncak M ranggi (Goa Jepang) telah mendorong masyarakat dan pengelola desa wisata (pokdarwis) untuk melengkapi sajian kuliner dengan mendirikan warung-warung. Namun, dari hasil pengamatan awal sajian kulinernya baik menu makan dan minum masih sama dengan warung-warung makan pada umumnya. Belum ada kuliner khas baik makanan atau minuman yang dikreasi menjadi sajian khas yang memiliki daya tarik bagi wisatawan. Beberapa orang telah mencoba membuat formula minuman, berdasarkan pertimbangan bahwa sebagian besar pengunjung merupakan wisatawan domestik. M ereka ratarata tertarik dengan minuman ketika beristirahat atau yang dikenal sebagai tradisi wedangan. Salah satu kreasi minuman khas adalah Wedang Ereng-Ereng. Nama ini diambil dari kondisi atau situs utama tujuan wisata yang berntuk lereng bukit (jawa : erengereng). Sesuai dengan tempatnya diharapkan nama wedang erengereng ini akan mudah dikenal, dihapal, dan diingat sehingga akan menjadi sajian utama kuliner khas yang menarik. U ntuk itu diperlukan upaya terus menerus untuk mengenalkan dan mempromosikan agar wedang erengereng tersebut menjadi terkenal sebagai minuman khastradisional yang dapat dijadikan ikon D esa W isata Seloharjo khususnya G oa Jepang.

Salah satu kegiatan yang dilakukan adalah mengadakan Festival Kuliner WedangE rengereng. Festival ini bertujuan untuk mendapatkan formula wedangyang memenuhi standar kualitas terbaik dan ditetapkan menjadi formula baku. Pada saatnya nanti, pen gembangan wedang erengereng oleh masyarakat harus berdasarkan standar kualitas yang ditetapkan sehingga terjadi keseragaman dalam hal bahan, takaran, cita rasa, dan penyajian. Tujuan 
yang lain adalah sebagai upaya promosi internal penyadaran potensi sajian wisata bagi masyarakat sehingga masyarakat bisa ikut mendukung. Pada akhirnya diharapkan dengan promosi yang terus menerus, wedang erengereng ini akan dikenal dan berkembang menjadi salah satu sumber pendapatan masyarakat sehingga bisa meningkatkan kesejahteraan.

U paya menggagas potensi sajian wisata ini sesuai dengan konsep $4 \mathrm{~A}$ yang dikembangkan oleh Echtner (2002), yaitu : sajian wisata (attractions), pelaku atau pengelola wisata (actors), pelaksanaan (actions), dan daya dukung masyarakat (atmospheres). Festival kuliner juga bertujuan untuk membentuk brand wedang erengereng menjadi salah satu penciri wisata. Konsep branding dalam wisata juga diken alkan oleh Pike (2005), dengan tujuan menjadi daya tarik yang tidak mudah tergantikan oleh yang lain.

\section{METODE PELAKSANAAN}

M itra dalam kegiatan ini adalah Pengelola D esa W isata (Pokdarwis) dan M asyarakat Pedukuhan Poyahan, N greco, dan Jelapan serta Desa Seloharjo Kecamatan Pundong Kabupaten Bantul. Sedangkan Desa Seloharjo sebenarnya terdiri atas 16 Pedukuhan atau D usun, tercantum dalam tabel 1.

Tabel 1. Nama Dusun di Desa Seloharjo, Kecamatan Pundong, Bantul

\begin{tabular}{cl}
\hline $\begin{array}{l}\text { Nama Pedukuhan/Dusun di Wilayah } \\
\text { Seloharjo Timur }\end{array}$ & $\begin{array}{l}\text { Nama Pedukuhan/Dusun di } \\
\text { Wilayah Seloharjo Barat }\end{array}$ \\
\hline 1. Dukuh & 9. Karangasem \\
2. Nambangan & 10. Ngentak \\
3. Pentung & 11. Biro \\
4. Darmojurang & 12. Kalipakem \\
5. Boboktempel & 13. Blali \\
6. Geger & 14. Ngreco \\
7. Kalinampu & 15. Poyahan \\
8. Soka & 16. Jelapan \\
\hline
\end{tabular}

Kegiatan festival ini dilakukan dengan empat tahapan terdiri atas: tahap persiapan, sosialisasi, pelaksanaan festival dan rencanatindak lanjut. Seluruh tahapan ini meli batkan peran serta masyarakat dari berbagai kalangan.

\section{HASIL DAN PEMBAHASAN}

\section{Tahap Persiapan}

Tahap persiapan ini meliputi pembentukan panitia kecil yang melibatkan komponen Kelompok Sadar W isata (Pokdarwis), pengelola wisata G oaj epang dan Puncak Surocolo (puncak M ranggi), dan aparat Pemerintah D esa dan Pengurus PKK. Setelah panitia kecil 
terbentuk, tahap selanjutnya adalah perancangan teknis pelaksanaan festival kuliner wedang erengereng. H asil diskusi panitia kecil menyepakati bahwafestival berlaku tertutup khusus bagi masyarakat Desa Seloharjo. Festival akan diikuti oleh seluruh dusun dengan menunjuk perwakilan satu tim tiap dusun, sehingga peserta diharapkan berjumlah 16 tim. Tempat festival akan terpusat di area parkir dan rest area W isata G oa Jepang Puncak M ranggi (puncak Surocolo). U ntuk menarik wisatawan akan disajikan hiburan berupa kesenian (musik) organ tunggal atau band Koesplus-an yang menjadi bagian kreativitas masyarakat D esa Seloharjo.

\section{Tahap Sosialisasi}

Tahap ini meliputi penyebaran informasi pada seluruh masyarakat dan calon peserta festival kuliner. Sosialisasi dilakukan oleh pemerintah desa Seloharjo melalui forumforum pertemuan warga, baik tingkat pedukuhan, forum RT, forum PKK, dan sebagainya. Sosialisasi resmi dilakukan dengan membuat undangan resmi ke masing-masing kepala dusun (kadus). Di undangan yang diberikan, dilampirkan tentang syarat dan ketentuan teknis pelaksanaan festival wedang erengereng. Sosialisasi juga dilakukan kepada khalayak untuk membangun kesadaran, perhatian, dan menarik minat masyarakat untuk menghadiri festival, "mencicipi" dan mengkonsumsi serta berlangganan wedang erengereng. Sosialisasi dilakukan den gan publikasi via span duk yang dipasang di tempat-tempat strategis. M elalui pemasangan spanduk, diharapkan masyarakat yang berkunjung ke wisata Goajepang dan Puncak Surocolo meningkat 100 \% daripada hari-hari biasa. Antusiasme masyarakat baik masyarakat Desa Seloharjo maupun wisatawan luar desa yang hadir menyaksikan festival juga tergolong tinggi.

Gambar spanduk Festival Kulier Wedang Ereng-ereng adalah sebagai berikut:

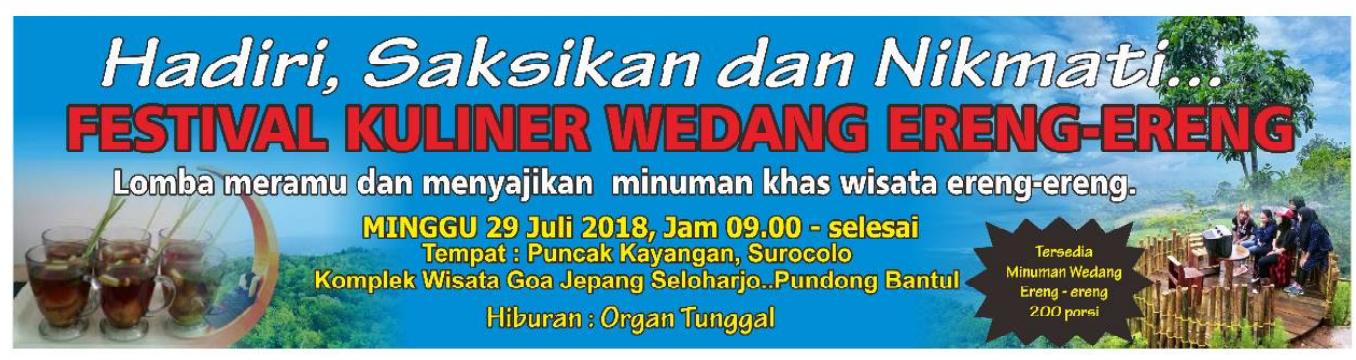

\section{Pelaksanaan Festival}

Pelaksanaan festival dikelola dan diken dalikan oleh Pengurus W isata G oa Jepang dan Puncak Surocolo. Bertempat di rest area (tempat parkir dan warung-warung makanan 


\section{9}

minuman) yang berjarak kurang lebih $200 \mathrm{~m}$ dari puncak Surocolo (M ranggi dan $\mathrm{G}$ oa Jepang). Pengurus wisata dan panitia mempersiapkan tempat festival berupa tenda dan meja pameran serta panggung festival dan hiburan. Stan festival disediakan 16 meja, namun peserta yang hadir dan ikut festival hanya 10 tim. Sementara meja stan yang kosong digunakan oleh beberapa warung untuk menjual aneka minuman dan makanan lain yang tersedia di warung wisata.

Pelaksanaan festival dimulai dengan penjelasan tentang aturan festival, dilajutkan penilaian oleh Juri dan minum gratisbagi pengunjung. Pengunjung yang minum dimohon untuk memberikan masukan kepada masingmasing pesertafestival menyan gkut penyajian dan cita rasa. Penilaian oleh Dewan Juri meliputi : formula, penyajian, dan cita rasa. D ewan Juri terdiri dari 3 orang yang seluruhnya berasal dari luar D esa Seloharjo sehingga lebih netral. Sebelum menilai, D ewan Juri mendapatkan pengarahan dan penjelasan tentang sejarah dan filosofi wedang erengereng sehingga makin lengkap bahan pertimbangan untuk melakukan penilaian

Perwakilan dari masing-masing dusun yang hadir menjadi peserta festival tercantum dalam tabel 2 sebagai berikut :

Tabel 2. Daftar Peserta Festival Wedang Ereng-ereng dana hasil penilaian festival

\begin{tabular}{clccr}
\hline No. & Tim Peserta Dusun & Total Nilai & Juara & Hadiah (Rp) \\
\hline 1. & Kalinampu & 68.5 & & \\
2. & Kalipakem & 72.5 & III & 250.000 \\
3. & Poyahan & 68.5 & & \\
4. & Ngreco & 66.5 & & \\
5. & Darmojurang & 59.5 & I & \\
6. & Nambangan & 74 & II & 5000.000 \\
7. & Soka & 73.5 & & \\
8. & Geger & 72 & & \\
9. & Jelapan & 68 & & \\
\hline
\end{tabular}

\section{RencanaTindak Lanjut}

Tujuan dari Festival Wedang Erengereng adalah menemukan formula yang dapat digunakan sebagai standar kualitas wedang erengereng. Standar kualitas yang dimaksud terkait macam dan takaran bahan yang digunakan, warna dan cita rasa. Penemu sekaligus peramu wedang erengereng sesungguhnya telah menciptakan formula standar, namun pada saat festival, peserta diberikan keleluasaan untuk berkreasi menambah bahan dengan komposisi tertentu. Bahan yang digunakan harus dicantumkan termasuk ukuran dan 
takarannya. Setelah diumumkan pemenang festival, maka hal yang harus ditindaklanjuti adalah :

a. Menetapkan formula stan dar yang didasarkan atas formula dari penemu atau peramu wedang erengereng ditambah atau dipadukan dengan formula dari pemenang festival dari juara 1 sampai dengan juara 3

b. Setelah ketemu formula dan menetapkan takaran bahan, maka perlu dilakukan kajian terhadap cara-cara terbaik dalam perlakuan dalam pemanfaatan dan penyajian bahan sehingga diperoleh kualitas bahan yang terbaik dan standar formula terbaik wedang erengereng

c. Perlu dilakukan sosialisasi standar formula wedang erengereng yang ditetapkan sehingga terjadi keseragaman pembuatan dan penyajian oleh siapapun baik untuk tujuan dikonsumsi sendiri maupun komersil

d. M erintis upaya promosi internal yaitu kepada masyarakat D esa W isata Seloharjo untuk menyajikan wedang erengereng dalam setiap forum-forum pertemuan masyarakat

e. Merintis berdirinya warung-warungatau kedai minuman yangmenjual wedang erengereng sebagai upaya promosi sebagai daya tarik wisata D esa Seloharjo

Perencanaan tindak lanjut merupakan bagian dari perencanaan desa wisata secara menyeluruh. M enurut Lansing dan De Vries (2007) pengembangan wisata perlu direncanakan untuk menjamin keberlanjutan (sustainability) baik pada aspek sumber daya alam maupun sumber daya manusianya. Pengembangan wisata perlu juga didukung kesiapan masyarakatnya. $\mathrm{H}$ al ini disebabkan karena keberlanjutan dan pengembangan desa wisata tergantung partisipasi masyarakat (community base tourism) seperti yang dikembangkan oleh Blackstok (2005).

\section{SIMPULAN}

1. Festival wedang erengereng merupakan satu upaya menciptakan sajian kuliner khas desa wisata Seloharjo.

2. Pelaksanaan festival wedang erengereng telah berhasil menjadi sarana sosialisasi dan promosi baik ke dalam masyarakat sebagai upaya menggugah kesadaran dukungan terhadap desa wisata maupun promosi keluar sebagai upaya meningkatkan daya tarik untuk berkunjung ke desa wisata Seloharjo

3. Diperlukan upaya tindak lanjut festival untuk menetapkan formula standar kualitas sehingga brand wedang erengereng akan seragam dalam penyajian, termasuk pembinaan teknis pemilihan bahan dan penyajian 
4. Diperlukan upaya sosialisasi terus menerus ke dalam masyarakat untuk menyajikan wedang erengereng sebagai minuman dalam setiap forum pertemuan masyarakat sebagai upaya mendapatkan dukungan dan rasa memiliki

5. Diperlukan rintisan beberapa outlet warung wedang ereng baik cafe atau angkringan wedang erengereng sebagai upaya promosi dalam rangka meningkatkan daya tarik kunjungan wisatawan di desa wisata Seloharjo

\section{D okumentasi Festival Wedang Erengereng}
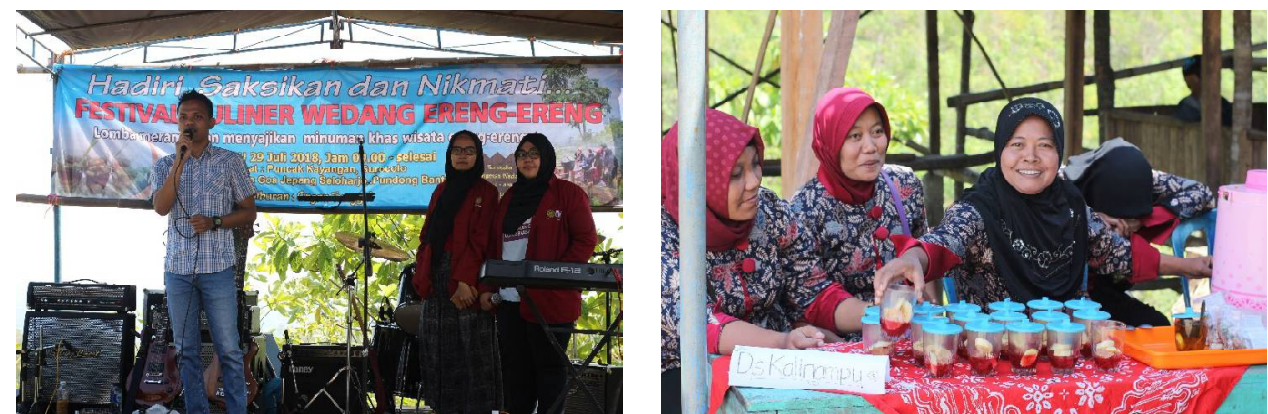

Gambar 1. Pembukaan Festival

Gambar 2. Penyajian Formula Wedang Ereng-ereng oleh Peserta

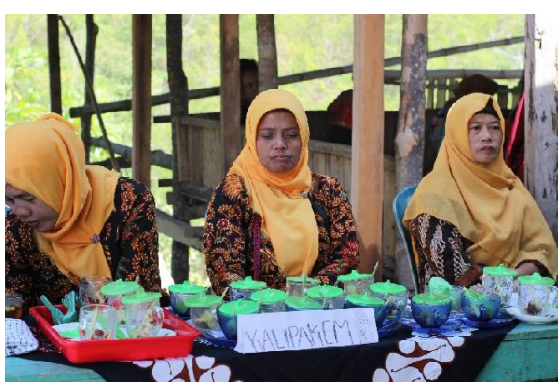

Gambar 3. Peserta Festival dari Berbagai Dusun

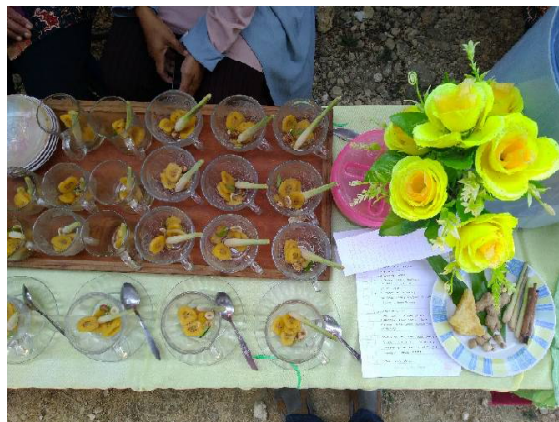

Gambar 5. Sajian Hidangan yang Dilombakan

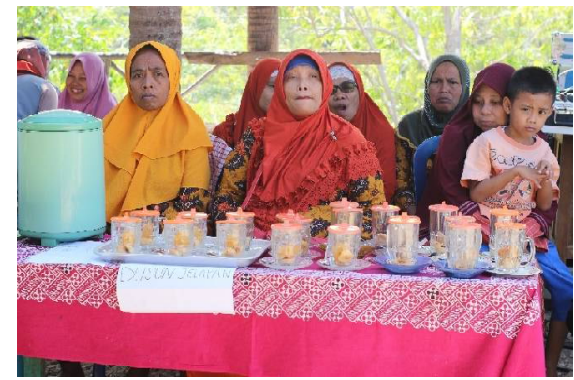

Gambar 4. Peserta Festival Wedang Ereng-ereng

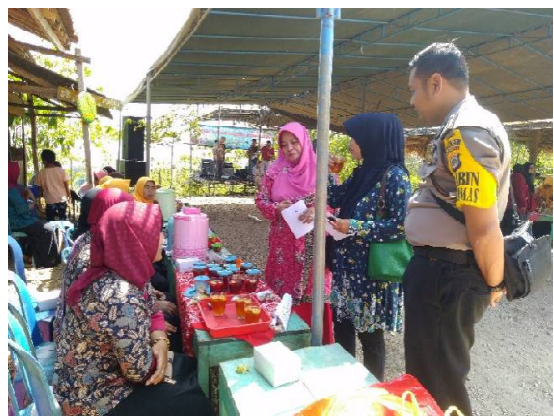

Gambar 6. Penilaiain oleh J uri dan Pengunjung 


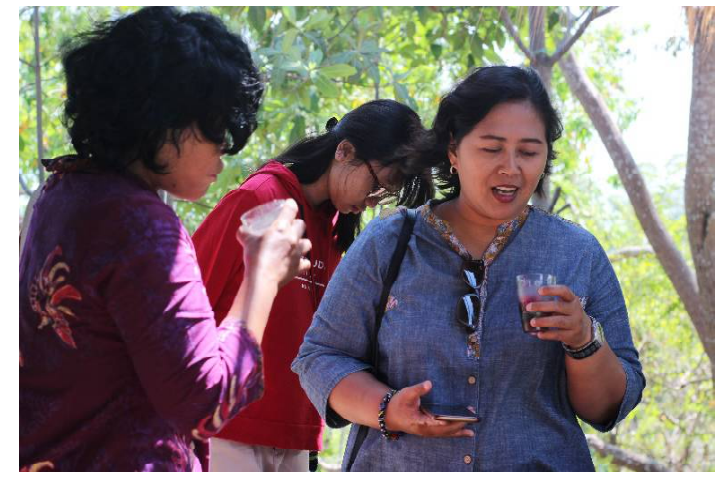

Gambar 7. Menikmati Wedang Ereng-ereng

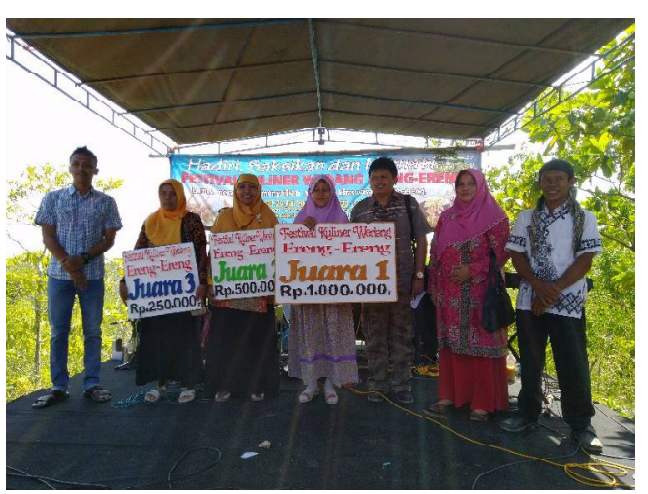

Gambar 8. Pengumungan J uara dan Penyerahan Hadiah

\section{DAFTAR PUSTAKA}

Blackstock, Kirstay. 2005. A critical look at community base tourism. Community Development Journal, 40/1 : 39 - 49

Echtner, Charlotte M. 2002. The content of the third world tourism marketing : a 4A Approach. International Journal of Tourism Research, 4 : 413-434

Gartner, William C. 2004. Rural tourism development in the USA.International J ournal of Tourism Research, $6: 151$ - 164
Lansing, Paul dan Paul De Vries. 2007. Sustainable tourism : ethical alternative or marketing ploy? Journal of Business Ethics, 72:77-85

Pike, Steven. 2005. Tourism destination branding complexity. The Journal of Product and Brand Management, 14/4: 258 - 259

Welford, Richard dan Bjarne Ytterhus.2004. Suistaneble development and tourism destination management : A case study of the Lillahammer region, Norwey. International Journal of Sustainable Development and World Ecology, 11:410 - 422 